Atmos. Chem. Phys., 17, 12813-12826, 2017

https://doi.org/10.5194/acp-17-12813-2017

(c) Author(s) 2017. This work is distributed under

the Creative Commons Attribution 3.0 License.

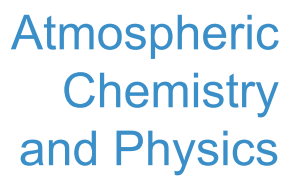

(c) (P)

\title{
Impact of agricultural emission reductions on fine-particulate matter and public health
}

\author{
Andrea Pozzer ${ }^{1}$, Alexandra P. Tsimpidi ${ }^{1}$, Vlassis A. Karydis ${ }^{1}$, Alexander de Meij ${ }^{2}$,a , and Jos Lelieveld ${ }^{1,3}$ \\ ${ }^{1}$ Atmospheric Chemistry Department, Max Planck Institute for Chemistry, Mainz, Germany \\ ${ }^{2}$ Noveltis, Sustainable Development, Rue du Lac, 31670 Labege, France \\ ${ }^{3}$ Energy, Environment and Water Research Center, The Cyprus Institute, Nicosia, Cyprus \\ a now at: MetClim, Varese, Italy
}

Correspondence to: Andrea Pozzer (andrea.pozzer@mpic.de)

Received: 27 April 2017 - Discussion started: 11 May 2017

Revised: 29 August 2017 - Accepted: 26 September 2017 - Published: 27 October 2017

\begin{abstract}
A global chemistry-climate model has been used to study the impacts of pollutants released by agriculture on fine-particulate matter $\left(\mathrm{PM}_{2.5}\right)$, with a focus on Europe, North America, East and South Asia. Simulations reveal that a relatively strong reduction in $\mathrm{PM}_{2.5}$ levels can be achieved by decreasing agricultural emissions, notably of ammonia $\left(\mathrm{NH}_{3}\right)$ released from fertilizer use and animal husbandry. The absolute impact on $\mathrm{PM}_{2.5}$ reduction is strongest in East Asia, even for small emission decreases. Conversely, over Europe and North America, aerosol formation is not immediately limited by the availability of ammonia. Nevertheless, reduction of $\mathrm{NH}_{3}$ can also substantially decrease $\mathrm{PM}_{2.5}$ concentrations over the latter regions, especially when emissions are abated systematically. Our results document how reduction of agricultural emissions decreases aerosol $\mathrm{pH}$ due to the depletion of aerosol ammonium, which affects particle liquid phase and heterogeneous chemistry. Further, it is shown that a $50 \%$ reduction of agricultural emissions could prevent the mortality attributable to air pollution by $\sim 250000$ people $\mathrm{yr}^{-1}$ worldwide, amounting to reductions of $30,19,8$ and $3 \%$ over North America, Europe, East and South Asia, respectively. A theoretical $100 \%$ reduction could even reduce the number of deaths globally by about 800000 per year.
\end{abstract}

\section{Introduction}

Atmospheric aerosol particles are a major constituent of ambient air and have a large impact on atmospheric chemistry, clouds, radiative transfer and climate and also induce adverse human health effects that contribute to mortality (IPCC, 2013; Lelieveld et al., 2015). Particulate matter (PM) with an aerodynamic diameter smaller than $2.5 \mu \mathrm{m}\left(\mathrm{PM}_{2.5}\right)$ contributes to air pollution through intricate interactions between emissions of primary particles and gaseous precursors, photochemical transformation pathways and meteorological processes that control transport and deposition.

As shown by Lelieveld et al. (2015) and Bauer et al. (2016), agricultural emissions play a leading role in the formation of $\mathrm{PM}_{2.5}$ in various regions of the world, for example in central and eastern Europe. Agricultural emissions are mostly related to animal husbandry and fertilizer use and to a lesser extent also to the burning of crop residues (Aneja et al., 2008): around $10 \%$ of worldwide biomass burning emissions can be ascribed to agricultural activities (Doering et al., 2009b). The general importance of agricultural emissions for air quality was also previously identified by a number of studies (e.g., Zhang et al., 2008; Tsimpidi et al., 2007; Megaritis et al., 2013) and recognized through environmental policies, (e.g., the establishment of ceilings for national emissions for ammonia by the European Union Clean Air Program). 
The dominant trace gas emitted by agricultural activities is ammonia $\left(\mathrm{NH}_{3}\right)$. Around $80-90 \%$ of the atmospheric $\mathrm{NH}_{3}$ emissions in industrialized regions are from the agricultural sector (Sotiropoulou et al., 2004; Lamarque et al., 2011; van Vuuren et al., 2011a, b). $\mathrm{NH}_{3}$ is formed and released during the decomposition of manure and organic matter, mostly from animal farming and the associated manure storage and field application, with an additional contribution from (synthetic) nitrogen fertilizer use. $\mathrm{NH}_{3}$ is a toxic gas at very high concentrations, with a pungent smell that irritates the eyes and respiratory system. $\mathrm{NH}_{3}$ is also a major alkaline gas in the atmosphere and plays an important role in neutralizing acids in the aerosol and cloud liquid phase, forming ammonium sulfate and ammonium nitrate (ammonium salts) (Behera et al., 2013). Therefore $\mathrm{NH}_{3}$ contributes to secondary aerosol formation and the overall particulate matter burden, and decreases the acidity of the aerosols, which in turn increases the solubility of weak acids (e.g., $\mathrm{HCOOH}, \mathrm{SO}_{2}$ ). The aerosol $\mathrm{pH}$ plays an important role in the reactive uptake and release of gases, which can affect ozone chemistry, particle properties such as hygroscopic growth and scattering efficiency of sunlight and deposition processes (Zhang et al., 2007; Thornton et al., 2010; Pathak et al., 2011).

Tsimpidi et al. (2007) showed that a $50 \%$ reduction of $\mathrm{NH}_{3}$ emissions would lead to a 4 and $9 \%$ decrease in $\mathrm{PM}_{2.5}$ over the eastern USA in July and January, respectively. The reduction of $\mathrm{NH}_{3}$ emissions was found to be the most effective $\mathrm{PM}_{2.5}$ control measure for the winter period over the eastern USA compared to similar reductions of $\mathrm{SO}_{2}, \mathrm{NO}_{x}$ and VOC emissions (Pinder et al., 2008; Tsimpidi et al., 2007, 2008; Karydis et al., 2011). Megaritis et al. (2013) and Bessagnet et al. (2014) found that over Europe the reduction of $\mathrm{NH}_{3}$ emissions is the most effective control strategy used to mitigate $\mathrm{PM}_{2.5}$ in both summer and winter, mainly due to a significant decrease of ammonium nitrate. Further, De Meij et al. (2009), showed that reducing the $\mathrm{NH}_{3}$ emissions from agriculture by $50 \%$ could result in a decrease of $\mathrm{PM}_{2.5}$ concentrations up to $2.4 \mu \mathrm{g} \mathrm{m}^{-3}$ over the Po Valley region (Italy). This confirms the finding of de Meij et al. (2006), who showed that for short-lived species like $\mathrm{NO}_{x}$ and $\mathrm{NH}_{3}$, short-term fluctuations of the emissions play an important role in the formation of nitrate aerosol. According to Wang et al. (2011), $\mathrm{NH}_{3}$ emissions contribute 8-11\% to $\mathrm{PM}_{2.5}$ concentrations in eastern China, which is comparable to the contributions of $\mathrm{SO}_{2}(9-11 \%)$ and $\mathrm{NO}_{x}(5-11 \%)$ emissions. However, the air quality benefits of controlling $\mathrm{NH}_{3}$ emissions could be offset by the potential enhancement of aerosol acidity. Weber et al. (2016) showed that, despite the large investments in sulfur dioxide emission reductions, the acid/base gas particle system in the southeastern USA is buffered by the partitioning of semivolatile $\mathrm{NH}_{3}$, making the $\mathrm{pH}$ insensitive to $\mathrm{SO}_{2}$ controls. Several studies have been performed on the impact of $\mathrm{NH}_{3}$ on aerosol nitrate (Pye et al., 2009; Heald et al., 2012; Schaap et al., 2004; Pinder et al., 2007; Holt et al., 2015) and sulfate (Redington et al., 2009;

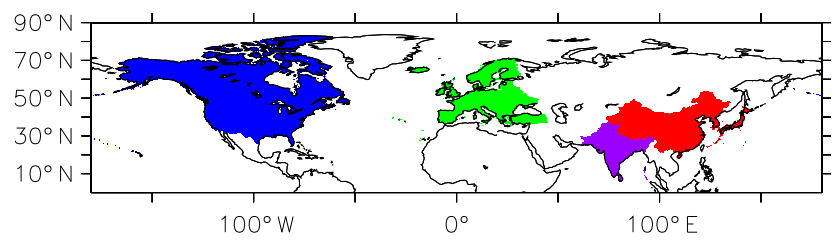

Figure 1. Regions addressed in this study, i.e., North America (blue), Europe (green), South Asia (purple) and East Asia (red).

Paulot et al., 2016; Wang et al., 2011), mostly with a regional rather than a global view.

As $\mathrm{PM}_{2.5}$ has been clearly associated with many health impacts, including acute lower respiratory infections (ALRI), cerebrovascular disease (CEV), ischaemic heart disease (IHD), chronic obstructive pulmonary disease (COPD) and lung cancer (LC) (Burnett et al., 2014). Due to its strong contribution to the $\mathrm{PM}_{2.5}$ mass, control strategies in $\mathrm{NH}_{3}$ emissions could possibly reduce the mortality attributable to air pollution, and air quality policy in Europe does indeed include ceilings for $\mathrm{NH}_{3}$ emissions (Kuklinska et al., 2015). Studies on $\mathrm{PM}_{2.5}$ reduction due to $\mathrm{NH}_{3}$ control have been performed regionally both for Europe (Brandt et al., 2013) and the USA (Paulot and Jacob, 2014; Muller and Mendelsohn, 2007), while a detailed analysis on the global scale was performed by Lee et al. (2015), who showed the importance of ammonia as a contributor to mortality attributable to air pollution. Nevertheless, Lee et al. (2015) assumed an ammonia reduction of $10 \%$, and the health effects were linearized around the present-day concentrations. As the exposure-response functions, linking $\mathrm{PM}_{2.5}$ to mortality attributable to air pollution, are highly nonlinear at relatively low concentrations, the mortality reduction estimation could change drastically for strong reductions of ammonia emissions. Therefore, in this work, more aggressive reductions are studied (see Sect. 2).

Furthermore, there is a need to not only investigate the impact of $\mathrm{NH}_{3}$ emission reductions on $\mathrm{PM}_{2.5}$ concentrations, but also account for particle acidity and aerosol composition. The goal of this work is to understand the impact of global agricultural emissions on model-simulated $\mathrm{PM}_{2.5}$ concentrations, the effects on aerosol $\mathrm{pH}$ and the potential consequences for human health, with a focus on four continental regions where air quality limits and guidelines for $\mathrm{PM}_{2.5}$ are often exceeded, i.e., North America, Europe, South and East Asia. North America is defined as the region that encompasses the USA and Canada; Europe is represented by the European continent (including Turkey) excluding Russia; South Asia includes India; Sri Lanka, Pakistan, Bangladesh, Nepal and Buthan; while the East Asia region includes China, North and South Korea and Japan (see Fig. 1).

This work may also support policy actions aimed at controlling ammonia emissions, e.g., formulated in the European 


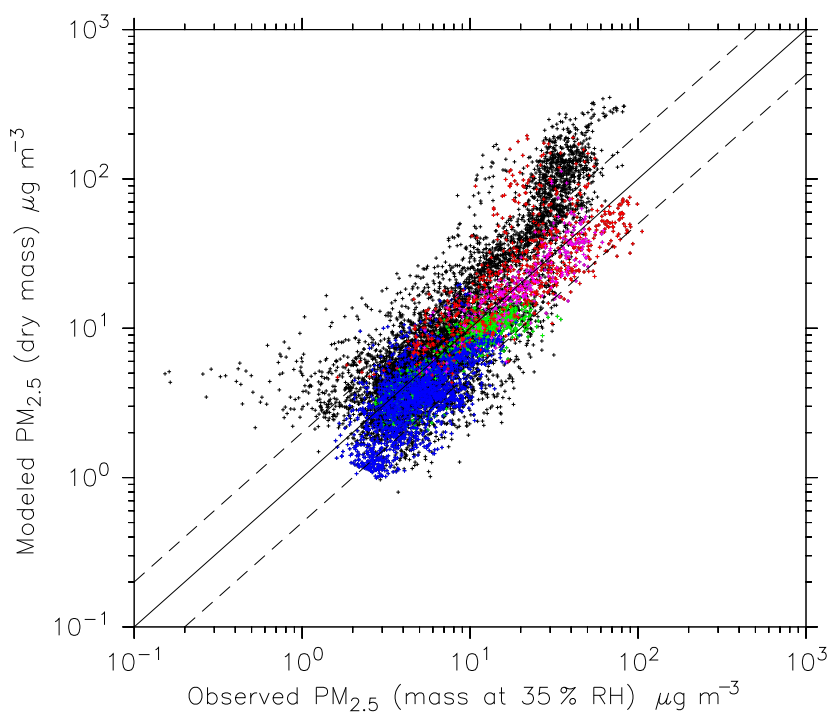

Figure 2. Scatter plot of observed and modeled yearly averaged concentrations of $\mathrm{PM}_{2.5}\left(\right.$ in $\mu \mathrm{g} \mathrm{m}^{-3}$ ). The colors denote the regions, i.e., blue is North America, green is Europe, purple is South Asia and red is East Asia. Black are locations outside these regions.

Union Clean Air Program (http://www.consilium.europa.eu/ en/policies/clean-air/), which sets ceilings for national emissions for sulfur dioxide, nitrogen oxides, volatile organic compounds, fine-particulate matter and ammonia.

\section{Methodology}

In this study the EMAC (ECHAM5/MESSy Atmospheric Chemistry) model version 1.9 was used. EMAC is a combination of the general circulation model ECHAM5 (Roeckner et al., 2006, version 5.3.01) and the Modular Earth Submodel System (Jöckel et al., 2005, MESSy, version 1.9). Extensive evaluation of the model can be found in Jöckel et al. (2006), Pozzer et al. (2007, 2012a), Pringle et al. (2010a) and de Meij et al. (2012a). ECHAM5 has been used at the T106L31 resolution, corresponding to a horizontal resolution of $\sim$ $1.1 \times 1.1^{\circ}$ of the quadratic Gaussian grid and with 31 vertical levels up to $10 \mathrm{hPa}$ in the lower stratosphere. The model setup is the same as that presented by Pozzer et al. (2012a, b) and is briefly summarized here. The anthropogenic emissions are for the year 2010 from the EDGAR-CIRCE (Doering et al., 2009a, c, Emission Database for Global Atmospheric Research) database, distributed vertically to account for different injection altitudes (Pozzer et al., 2009). Bulk natural aerosol emissions (i.e., desert dust and sea spray), are treated using offline monthly emissions files based on AEROCOM (Dentener et al., 2006) and hence are independent of the meteorological conditions. The atmospheric chemistry is simulated with the MECCA (Module Efficiently Calculating the Chemistry of the Atmosphere) submodel by Sander et al. $(2005,2011)$, and the aerosol microphysics and

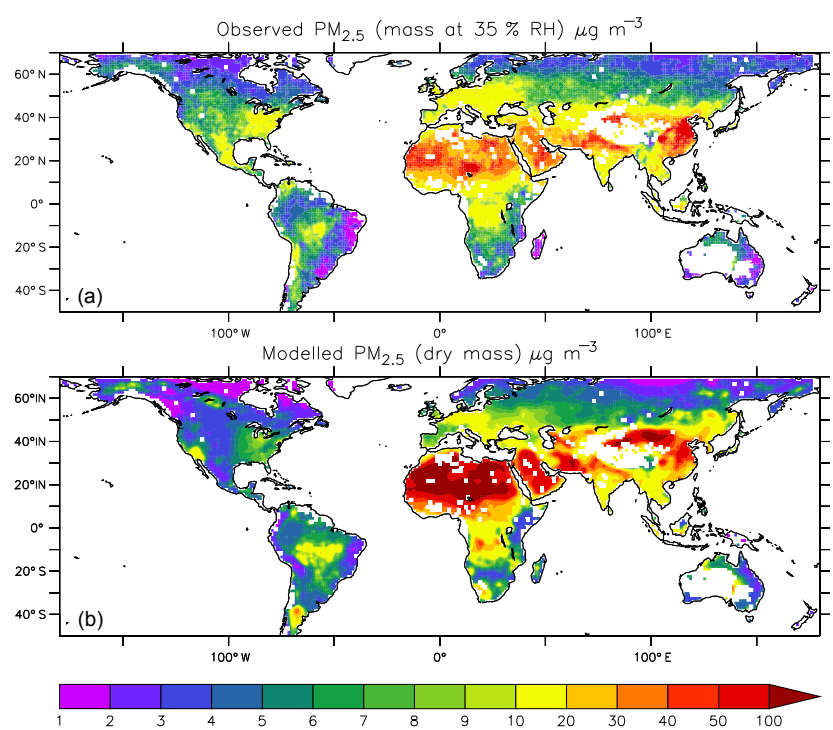

Figure 3. (a) Observed annual mean $\mathrm{PM}_{2.5}$ from (van Donkelaar et al., 2010), (b) simulated annual mean $\mathrm{PM}_{2.5}$ (REF simulation), both in $\mu \mathrm{g} \mathrm{m}^{-3}$.

gas-aerosol partitioning are calculated by the Global Modalaerosol eXtension (GMXe) aerosol module (Pringle et al., 2010a, b). Gas/aerosol partitioning is calculated using the ISORROPIA-II model (Fountoukis and Nenes, 2007; Nenes et al., 1998a, b). Following the approach of Pozzer et al. (2012b), the year 2010 is used as the reference year, the feedback between chemistry and dynamics was switched off, and therefore all simulations described here are based on the same (binary identical) dynamics and consequent transport of tracers.

Although Pozzer et al. (2012a) evaluated the model for the same configuration and emissions database, the emissions referred to the year 2005, while here the emissions for the year 2010 are used. Therefore the model is re-evaluated for the species of interest (i.e., $\mathrm{SO}_{4}^{2-}, \mathrm{NO}_{3}^{-}, \mathrm{NH}_{4}^{+}$and $\mathrm{PM}_{2.5}$ ). The model results of this study have been evaluated against satellite based $\mathrm{PM}_{2.5}$ estimates (van Donkelaar et al., 2010); the results are shown in Fig. 2 and are summarized in Table 1, also focusing on the four regions focus of this study (i.e., North America, Europe, South and East Asia). Compared to global satellite-derived $\mathrm{PM}_{2.5}$ concentrations this model version, with prescribed dust emissions, consistently overestimates $\mathrm{PM}_{2.5}$ over desert areas (see Fig. 2). However, the average concentration of $\mathrm{PM}_{2.5}$ at the surface in the regions of interest is within $30 \%$ of the observations. For Europe and South Asia, $95 \%$ of the simulated $\mathrm{PM}_{2.5}$ concentrations are within a factor of 2 of the observations, while for North America and East Asia this is about $80 \%$.

Further, $\mathrm{SO}_{4}^{2-}, \mathrm{NO}_{3}^{-}$and $\mathrm{NH}_{4}^{+}$have been compared with station observations from different databases, such as from EPA (United States Environmental Protection Agency), EMEP (European Monitoring and Evaluation Programme) 
Table 1. Summary of the comparison of model data to pseudoobservations of $\mathrm{PM}_{2.5}$ concentrations (van Donkelaar et al., 2010). OAM and MAM are the spatial arithmetic mean of the observations and of the model results (REF simulation), respectively (in $\mu \mathrm{g} \mathrm{m}^{-3}$ ), based on the annual averages. The model results were masked in locations where no observations are available. PF2 is the percentage of model results within a factor of 2 of the observations.

\begin{tabular}{lrrrr}
\hline Region & MAM & OAM & MAM/OAM & PF2 \\
\hline Europe & 9.00 & 11.96 & 0.75 & 0.95 \\
North America & 4.31 & 5.89 & 0.72 & 0.80 \\
South Asia & 24.49 & 24.95 & 0.98 & 0.95 \\
East Asia & 33.60 & 27.56 & 1.22 & 0.81 \\
World & 22.58 & 13.02 & 1.73 & 0.75 \\
\hline
\end{tabular}

Table 2. Summary of the comparison of model data to the observations of aerosol component concentrations. OAM and MAM are the spatial arithmetic mean of the observations and the model, respectively (in $\mu \mathrm{g} \mathrm{m}^{-3}$ ). PF2 is the percentage of model results within a factor of 2 in the observations.

\begin{tabular}{llrrrr}
\hline Species & Network & MAM & OAM & MAM/OAM & PF2 \\
\hline $\mathrm{SO}_{4}^{2-}$ & EPA & 1.22 & 1.18 & 1.03 & 85.5 \\
$\mathrm{SO}_{4}^{2-}$ & EMEP & 1.36 & 1.70 & 0.79 & 86.5 \\
$\mathrm{SO}_{4}^{2-}$ & EANET & 1.54 & 3.30 & 0.46 & 88.8 \\
$\mathrm{NO}_{3}^{-}$ & EPA & 0.65 & 0.42 & 1.54 & 63.0 \\
$\mathrm{NO}_{3}^{-}$ & EMEP & 2.08 & 1.15 & 1.81 & 32.6 \\
$\mathrm{NO}_{3}^{-}$ & EANET & 1.11 & 1.37 & 0.81 & 68.3 \\
$\mathrm{NH}_{4}^{+}$ & EPA & 0.77 & 0.79 & 0.97 & 88.0 \\
$\mathrm{NH}_{4}^{+}$ & EMEP & 1.11 & 1.07 & 1.03 & 74.6 \\
$\mathrm{NH}_{4}^{+}$ & EANET & 0.77 & 0.96 & 0.79 & 80.6 \\
\hline
\end{tabular}

and EANET (Acid Deposition Monitoring Network in East Asia) for the year 2010. The results are shown in Fig. 4 and summarized in Table 2.

While sulfate is well reproduced, with more than $\sim 85 \%$ of the model results within a factor of 2 compared to the observations, nitrate is overestimated in North America and Europe by $\sim 50 \%$, although nitric acid is reproduced accurately by the model (based on comparison with observations from Emmons et al., 2000; see Jöckel et al., 2006). As the nitrate concentrations seem to be on the high end of the observations, it must be acknowledged that the effect of reducing ammonia emissions from agriculture could be overestimated. On the other hand, nitrate predictions are in good agreement with the measurements over East Asia. Further, ammonium concentrations are well captured by the model, with more than $75 \%$ of the modeled results being within a factor of 2 compared to the observations. For ammonium, the annual averages estimated from model results compare well with the observations (see Table 2). Further, as shown by Pozzer et al. (2012a), simulated seasonal cycle of ammonium concentrations compares well with the observed one, both for Europe and Asia (with temporal correlations between model results

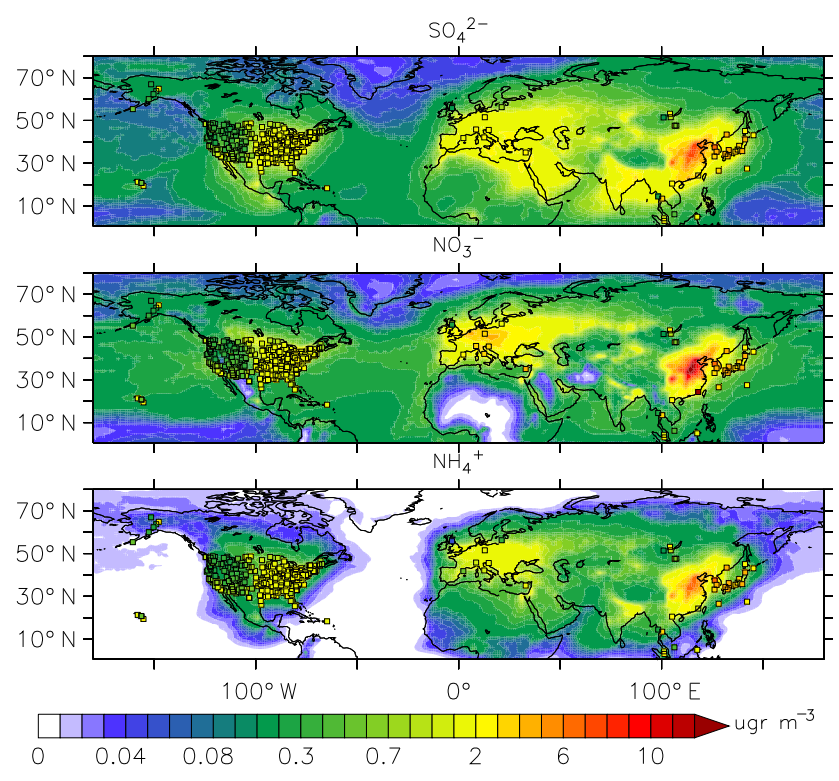

Figure 4. Simulated mean concentrations of $\mathrm{PM}_{2.5}$ components $\left(\mathrm{SO}_{4}^{2-}, \mathrm{NO}_{3}^{-}\right.$and $\left.\mathrm{NH}_{4}^{+}\right)$in $\mu \mathrm{g} \mathrm{m}^{-3}$ at the surface for the year 2010 , with observations from EPA, EMEP and EANET (averaged over the same period) overlaid.

and observations above 0.7 and 0.5 , respectively). However, this is not the case on the east coast of the USA, where the correlation is below 0.2. As suggested by Pozzer et al. (2012a), this is due to the wrong seasonality of the ammonia emissions, driven by an underestimation of the livestock emissions, which have a maximum in summer and should account for $80 \%$ of the annual $\mathrm{NH}_{3}$ emissions in the region (Battye et al., 2003). The agricultural emissions of ammonia in this region in the model reproduce mostly the fertilizer application as described by Goebes et al. (2003) and therefore the real seasonality of the ammonia emissions is missing (Paulot et al., 2014). The seasonal results over the USA should hence be taken with caution. Further evaluation can be found in Pozzer et al. (2012a, b) and de Meij et al. (2012b).

In the current analysis four simulations with the EMAC model have been performed to study the impacts on $\mathrm{PM}_{2.5}$ components: the evaluated reference simulation (REF) and three sensitivity calculations in which the agricultural emissions have been reduced by different percentages, $50 \%$ in simulation REF_50, $75 \%$ in simulation REF_75 and $100 \%$ (i.e., removing all agricultural emissions) in simulation REF_100.

The $\mathrm{NO}_{x}$ emissions from agriculture are $0.7 \mathrm{Tg}(\mathrm{N}) \mathrm{yr}^{-1}$, i.e., only $\sim 1.7 \%$ of the total $\mathrm{NO}_{x}$ emissions. Most importantly, $34.3 \mathrm{Tg}(\mathrm{N}) \mathrm{yr}^{-1}$ of $\mathrm{NH}_{3}$ are emitted by agricultural activities, such as livestock manure and $\mathrm{N}$ mineral fertilizers, accounting for $\sim 80 \%$ of the anthropogenic and $\sim 67 \%$ of the total global ammonia emissions. 
Agricultural waste burning is responsible for the emissions of $0.1 \mathrm{Tg}(\mathrm{S}) \mathrm{yr}^{-1}$ of $\mathrm{SO}_{2}$ (less than $1 \%$ of the total $\mathrm{SO}_{2}$ emissions) and $23.2 \mathrm{Tg}(\mathrm{C}) \mathrm{yr}^{-1}$ of $\mathrm{CO}(\sim 5 \%$ of the total $\mathrm{CO}$ emissions), as well as 0.4 and $1.9 \mathrm{Tg}(\mathrm{C}) \mathrm{yr}^{-1}$ of black carbon (BC) and organic carbon (OC), respectively, representing in both cases $\sim 5 \%$ of their total emissions.

Considering these emission magnitudes, the main effects of agricultural emissions on $\mathrm{PM}_{2.5}$ are expected from $\mathrm{NH}_{3}$ through gas-particle partitioning. Therefore, the ammonia emissions used in this work have been compared to other used databases, such as EDGARv4.3.1 (Emission Database for Global Atmospheric Research, Crippa et al., 2016) and RCP85 (Representative Concentration Pathways van Vuuren et al., 2011b, a). These data sets differ globally by $15 \%\left(40.26,47.49\right.$ and $40.62 \mathrm{Tg} \mathrm{yr}^{-1}$ for EDGAR-CIRCE, EDGARv4.3.1 and RCP85). This reflects the uncertainties in the emission estimates of ammonia, which could be up to $50 \%$ on a local scale (Beusen et al., 2008). The implementation of bidirectional exchange of ammonia between the soil and atmosphere may improve the emissions from livestock, although this approach is still associated with underestimates of emissions (Zhu et al., 2015). Further, ammonia emitted from traffic is included ( $\sim 1 \%$ of total ammonia emissions), although toward the lower end of what has been estimated by Sun et al. (2016).

As shown by Lorenz and Steffens (1997), Webb et al. (2006) and Kai et al. (2008), a sustainable reduction of ammonia emissions between 20 to $90 \%$ could be achieved, depending on the emission process and the methodology applied (e.g., slurry acidification, adjustment in slurry application, under-floor drying of broiler manure in buildings, replacing urea with ammonium nitrate). As the efficiencies of the abatement processes are not well established (Misselbrook et al., 2002), fixed relative reductions have been applied here to all agricultural emissions. Webb et al. (2006) showed that for the United Kingdom a moderate reduction in ammonia emission is easily affordable, while the costs are likely to increase exponentially for reductions above $25 \%$. The same control measures would be even more difficult to apply in countries in which livestock production is projected to largely increase (such as Asia; Delgado et al., 2001), where they should be adopted on a large scale.

\section{Results and discussion}

\subsection{Impact on $\mathrm{PM}_{2.5}$}

In Figure 5 the relative annual average surface $\mathrm{PM}_{2.5}$ concentration changes between simulations REF_50, REF_75, REF_100 and REF are presented. These simulations reflect the impact on $\mathrm{PM}_{2.5}$ of policies imposing an overall decrease in the agricultural emissions of 50, 75 and $100 \%$, respectively. In Table 3 the predicted $\mathrm{PM}_{2.5}$ concentrations and $\mathrm{pH}$ for all simulations are also listed. The largest ef- fects are found over Europe, North America and China; the latter have a smaller relative intensity. A 50, 75 and $100 \%$ reduction of ammonia emissions would reduce the annual and geographical mean $\mathrm{PM}_{2.5}$ levels over Europe by $\sim 1.0 \mu \mathrm{g} \mathrm{m}^{-3}(11 \%), 1.8 \mu \mathrm{g} \mathrm{m}^{-3}(19 \%)$ and $3.1 \mu \mathrm{g} \mathrm{m}^{-3}$ (34\%) compared to the reference annual surface concentration of $8.9 \mu \mathrm{g} \mathrm{m}^{-3}$. The same relative emission decreases in North America lead to $\mathrm{PM}_{2.5}$ concentration reductions of $0.3 \mu \mathrm{g} \mathrm{m}^{-3}(8 \%), 0.5 \mu \mathrm{g} \mathrm{m}^{-3}(12 \%)$ and $0.69 \mu \mathrm{g} \mathrm{m}^{-3}(16 \%)$, respectively, compared to a reference annual surface concentration of $4.0 \mu \mathrm{g} \mathrm{m}^{-3}$. Over East Asia the absolute decrease in the annual average $\mathrm{PM}_{2.5}$ concentration near the surface is $1.6 \mu \mathrm{g} \mathrm{m}^{-3}(5 \%), 2.7 \mu \mathrm{g} \mathrm{m}^{-3}(8 \%)$ and $4.08 \mu \mathrm{g} \mathrm{m}^{-3}(13 \%)$ for the three scenarios. Although the absolute changes in East Asia (relative to a reference value of $31.1 \mu \mathrm{g} \mathrm{m}^{-3}$ ), are larger than the corresponding changes estimated over $\mathrm{Eu}-$ rope and North America, the relative changes are smaller. In fact, the fraction of fine-particle mass that is directly ammonia sensitive (i.e., $\left.\left(\mathrm{NH}_{4}^{+}+\mathrm{NO}_{3}^{-}\right) / \mathrm{PM}_{2.5}\right)$ is relatively smaller in East Asia $(\sim 13 \%)$ than in Europe $(\sim 27 \%)$ and North America $(\sim 17 \%)$, and a reduction of $\mathrm{NH}_{3}$ emissions would mainly decrease the nitrate and ammonium components rather than the predominant components of $\mathrm{PM}_{2.5}$ in this part of the world. Over South Asia, this effect is even more pronounced. The decreased emissions, in fact, have a negligible impact on annual average $\mathrm{PM}_{2.5}$, reducing it by $0.62(2 \%), 0.76(3 \%)$ and $1.44(6 \%) \mu \mathrm{g} \mathrm{m}^{-3}$, for reductions of ammonia emissions of 50, 75 and $100 \%$. The fraction of fine-particle mass sensitive to ammonia in this region is very low $(3 \%)$, since more than $90 \%$ of the aerosol mass is not formed by the ammonium-sulfate-nitrate components, but rather by organic carbon ( $\sim 45 \%$ of the total mass) and dust ( $\sim 35 \%$ of the total mass).

In all four regions considered here, the impact of $\mathrm{NH}_{3}$ emission reduction on $\mathrm{PM}_{2.5}$ concentrations is strongest in winter. This is related to the enhanced $\mathrm{NH}_{4} \mathrm{NO}_{3}$ partitioning in the gas phase due to the higher temperatures in summer, so that a reduction of $\mathrm{NH}_{3}$ influences the gas-phase concentrations more strongly than the particulate phase during this season. The opposite happens during the winter season. Additionally, in the REF simulation, the winter total nitrate (gas and aerosol) concentrations are somewhat higher than during the summer over Europe (5.3 vs $4.5 \mu \mathrm{g} \mathrm{m}^{-3}$ ), USA (1.5 vs $1.0 \mu \mathrm{g} \mathrm{m}^{-3}$ ), South Asia (10.0 vs 3.4) and East Asia (8.2 vs $\left.4.5 \mu \mathrm{g} \mathrm{m}^{-3}\right)$. This is related to the lower boundary layer height in winter, causing less dilution of the emitted tracers, although in the Northern Hemisphere the ammonia winter emissions are generally lower than in summertime.

The total $\mathrm{PM}_{2.5}$ sulfate (i.e., $\mathrm{SO}_{4}^{2-}+\mathrm{HSO}_{4}^{-}$) is not directly affected by $\mathrm{NH}_{3}$ emission reductions since it can exist in the aerosol phase in the form of ammonium sulfate or ammonium bisulfate, depending on the ammonium concentration. However, sulfate formation in the aqueous phase is limited by high acidity. As a consequence, the $\mathrm{SO}_{4}^{2-}$ concentration in $\mathrm{PM}_{2.5}$ decreases, annually averaged, by 11,23 and $75 \%$ 


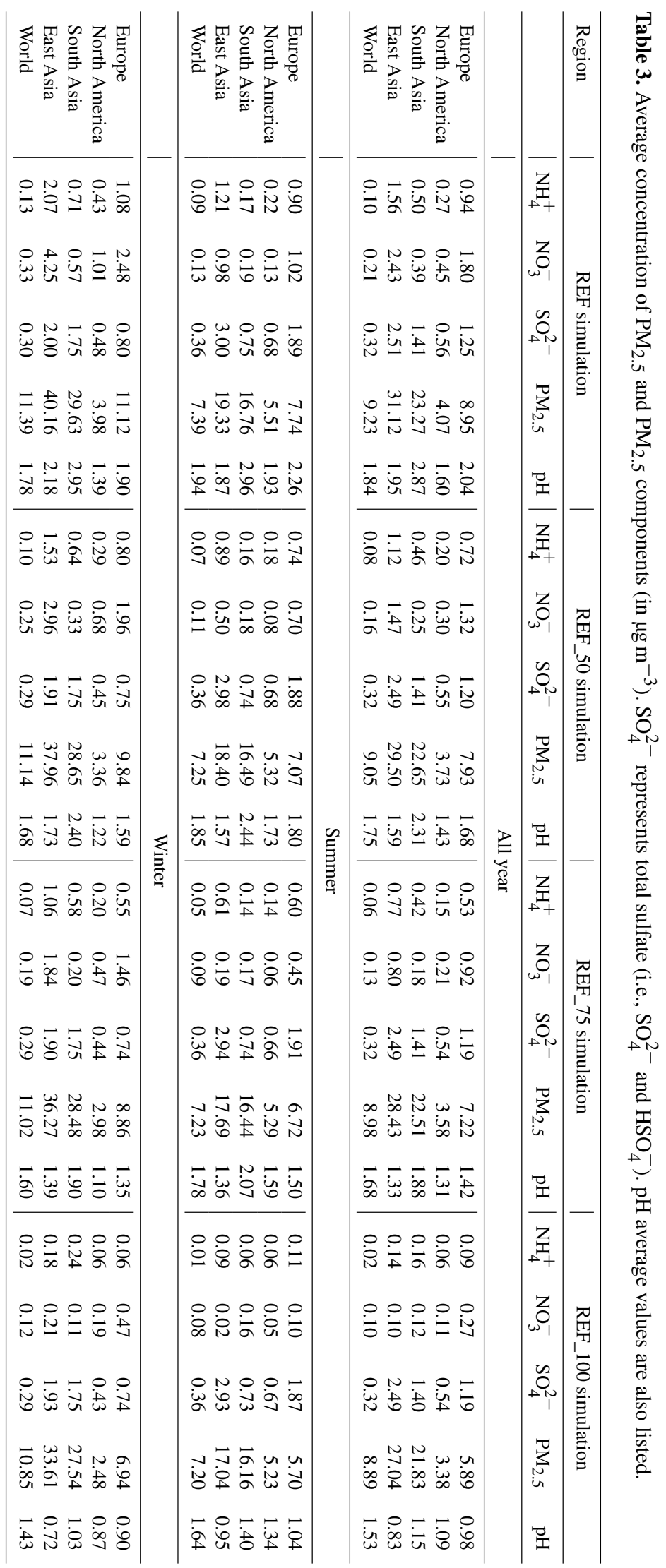



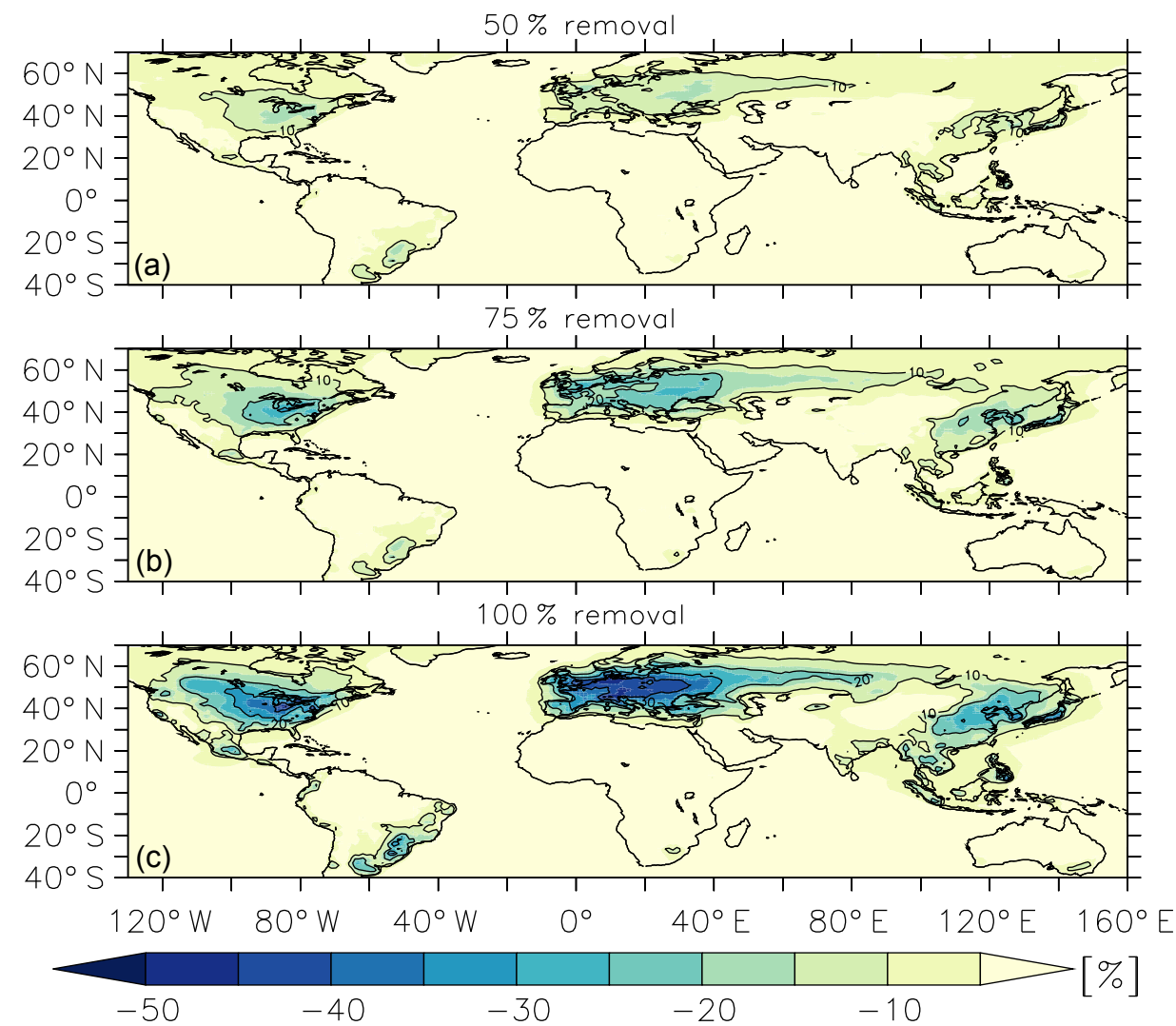

Figure 5. Relative annual average surface $\mathrm{PM}_{2.5}$ concentration changes (in \%) from the three scenarios with agricultural emissions reductions of 50,75 and $100 \%$ (a, b and $\mathbf{c}$, respectively).

over Europe, by 15, 28 and $57 \%$ over North America, by 3, 7 and $50 \%$ over South Asia and by 18, 36 and $74 \%$ over East Asia for a reduction of 50, 75 and $100 \%$ of agricultural emissions. This is counterbalanced by an increase of $\mathrm{HSO}_{4}^{-}$ concentrations.

For Europe and North America, the simultaneous decrease of nitrate and ammonium makes the reduction of agricultural emissions very effective, especially in winter, in accordance with the findings of Tsimpidi et al. (2007) and Megaritis et al. (2013). Furthermore, the relationship between ammonia and $\mathrm{PM}_{2.5}$ concentrations is not linear and is governed by the sulfate / nitrate ratio (Tsimpidi et al., 2007). Our EMAC simulations reveal that the $\mathrm{PM}_{2.5}$ response to $\mathrm{NH}_{3}$ emissions is more linear in winter (compared to summer), since the sulfate / nitrate ratio is generally lower.

Following Makar et al. (2009), the particle neutralization ratio $\left(\mathrm{PNR}\right.$, i.e., $\left.\left(\mathrm{NH}_{4}^{+}\right) /\left(2\left(\mathrm{SO}_{4}^{2-}+\mathrm{HSO}_{4}^{-}\right)+\mathrm{NO}_{3}^{-}\right)\right)$calculations indicate that in Europe and East Asia (both with PNR equal to 0.20) ammonia concentrations must be decreased relatively more strongly than in North America and South Asia (PNR equal to 0.13 for both regions) to reach the ammonia-limited regime, i.e., before $\mathrm{PM}_{2.5}$ can be efficiently controlled by decreasing $\mathrm{NH}_{3}$ emissions.
On the other hand, the absolute reduction in $\mathrm{PM}_{2.5}$ depends on the fraction of fine-particulate mass that is directly ammonia sensitive. As a consequence, Europe has the overall largest potential of reducing annual averaged $\mathrm{PM}_{2.5}$ by strongly controlling $\mathrm{NH}_{3}$ emissions (up to $34 \%$ ), followed by North America (up to $16 \%$ ) and East Asia (up to $13 \%$ ), while South Asia has very limited potential (up to $6 \%$ ). Thus it follows that, although the emission decrease needed in Europe to reach the ammonia-limited regime is larger than in North America, the effective gain of further reduction - once this regime is reached - is considerably larger. In East Asia, where $\mathrm{PM}_{2.5}$ is not ammonia limited, even strong emission decreases would reduce the $\mathrm{PM}_{2.5}$ mass by up to $13 \%$ on the annual average.

\subsection{Impact on particle pH}

In addition to the significant reductions in $\mathrm{PM}_{2.5}$ from ammonia emission controls, which are considered beneficial to human health, we note that the aerosol $\mathrm{pH}$ can change substantially. This has the potential of altering the particle liquid phase and heterogeneous chemistry, including reactive uptake coefficients, the outgassing of relatively weak acids and the $\mathrm{pH}$ of cloud droplets that grow on aerosols, which in turn affects aqueous-phase sulfate formation. Ammonia is 


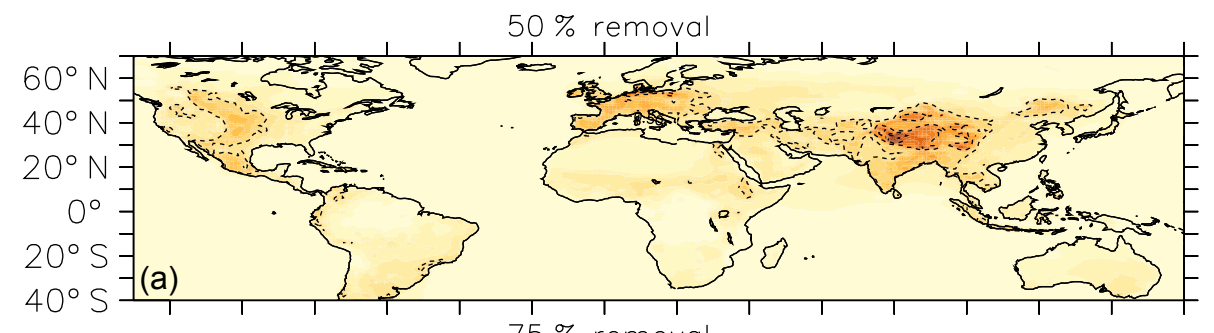

$75 \%$ removal
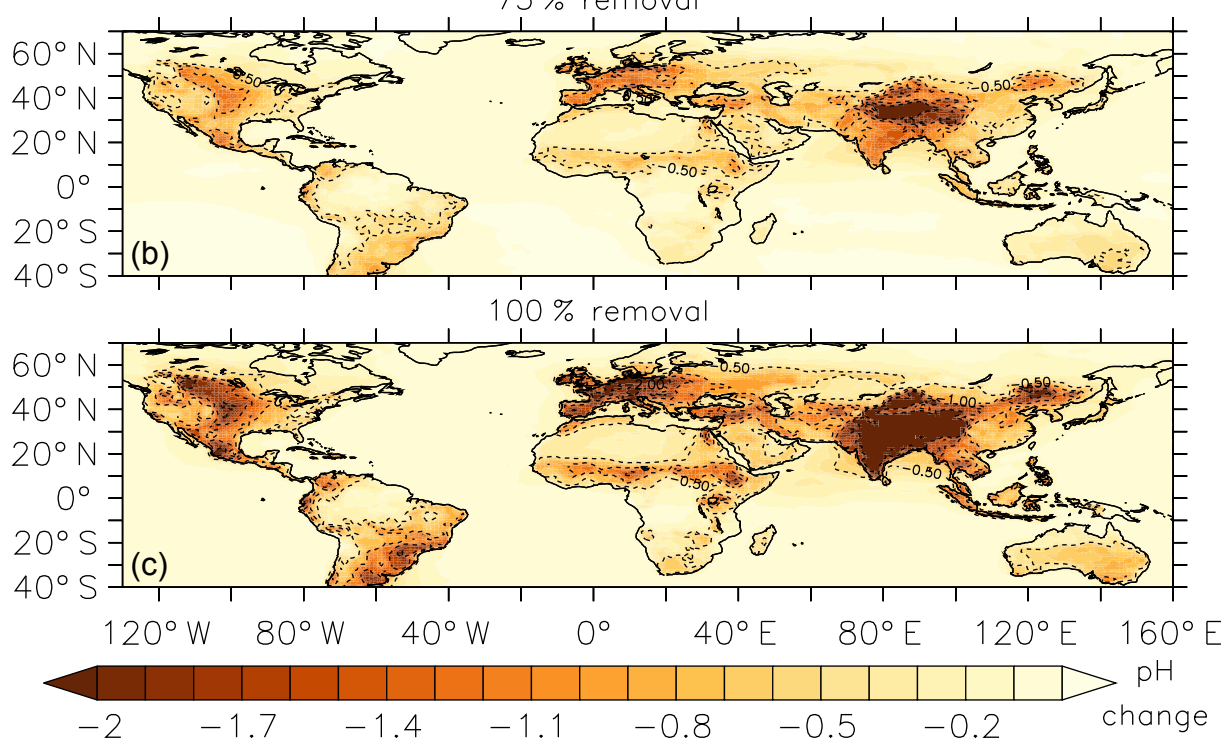

Figure 6. Absolute annual average surface aerosol $\mathrm{pH}$ changes (all modes) from three scenarios with agricultural emission reductions of 50, 75 and $100 \%$ (a, b and c, respectively).

in fact the most abundant and efficient base for controlling the aerosol composition over anthropogenically influenced regions and neutralizes sulfuric, nitric and other acids.

In the REF simulation, the particles over the focal regions are highly acidic, consisting mainly of ammonium sulfate and ammonium nitrate, as also shown by Weber et al. (2016). Figure 6 illustrates how the aerosol $\mathrm{pH}$ can drop due to $\mathrm{NH}_{3}$ emission decreases. Over Europe, the calculated mean aerosol $\mathrm{pH}$ decreases by $0.35,0.62$ and $1.05 \mathrm{pH}$ units for the REF_50, REF_75 and REF_100 simulations. The calculations indicate similar decreases over East Asia (0.35, 0.62 and $1.11 \mathrm{pH}$ units) and smaller decreases over North America $(0.16,0.29$ and $0.51 \mathrm{pH}$ units), while the largest decreases are present over South Asia (0.56, 0.99 and $1.72 \mathrm{pH}$ units). Over South Asia, the impact of ammonia emissions reduction on $\mathrm{pH}$ is the largest (see Fig. 6) despite the relatively small impact of the same changes on $\mathrm{PM}_{2.5}$. This is due to the high sulfate concentrations, which are neutralized in decreasing order by the presence of ammonium in the three sensitivity simulations. The $\mathrm{pH}$ of $\mathrm{PM}_{2.5}$ is therefore more sensitive to ammonia emissions (and its atmospheric concentrations) than sulfate, as shown by Weber et al. (2016). This increase of acidity for reduced ammonia emissions would have a strong influence on halogen activation and aerosol-gas equilibrium of weak acids in the atmosphere.

Contrary to what was found for $\mathrm{PM}_{2.5}$, the reduction of $\mathrm{pH}$ is larger in summer than in winter. This is due to the lower concentrations of ammonia in the aerosol phase in summer (see Sect. 3.1), i.e., with relatively low neutralization capability in this season. Therefore, any further reduction of ammonia emissions would strongly reduce the neutralization potential and therefore increase even more drastically the acidity of the particles.

It should be mentioned that in the present calculations the chemical impact of alkaline desert dust is not taken into account, which can contribute significantly to $\mathrm{PM}_{2.5}$ over areas downwind of the deserts (Karydis et al., 2016), e.g., over the Indian subcontinent in the dry season and over eastern China in spring (Wang et al., 2013), so that the $\mathrm{pH}$ effect described here is probably an upper limit. This topic is subject of a publication in preparation.

\subsection{Impact on public health}

From the simulated $\mathrm{PM}_{2.5}$ concentrations, the mortality attributable to air pollution has been calculated following the method of Lim et al. (2013) and described in detail in Lelieveld et al. (2015). The exposure-response func- 

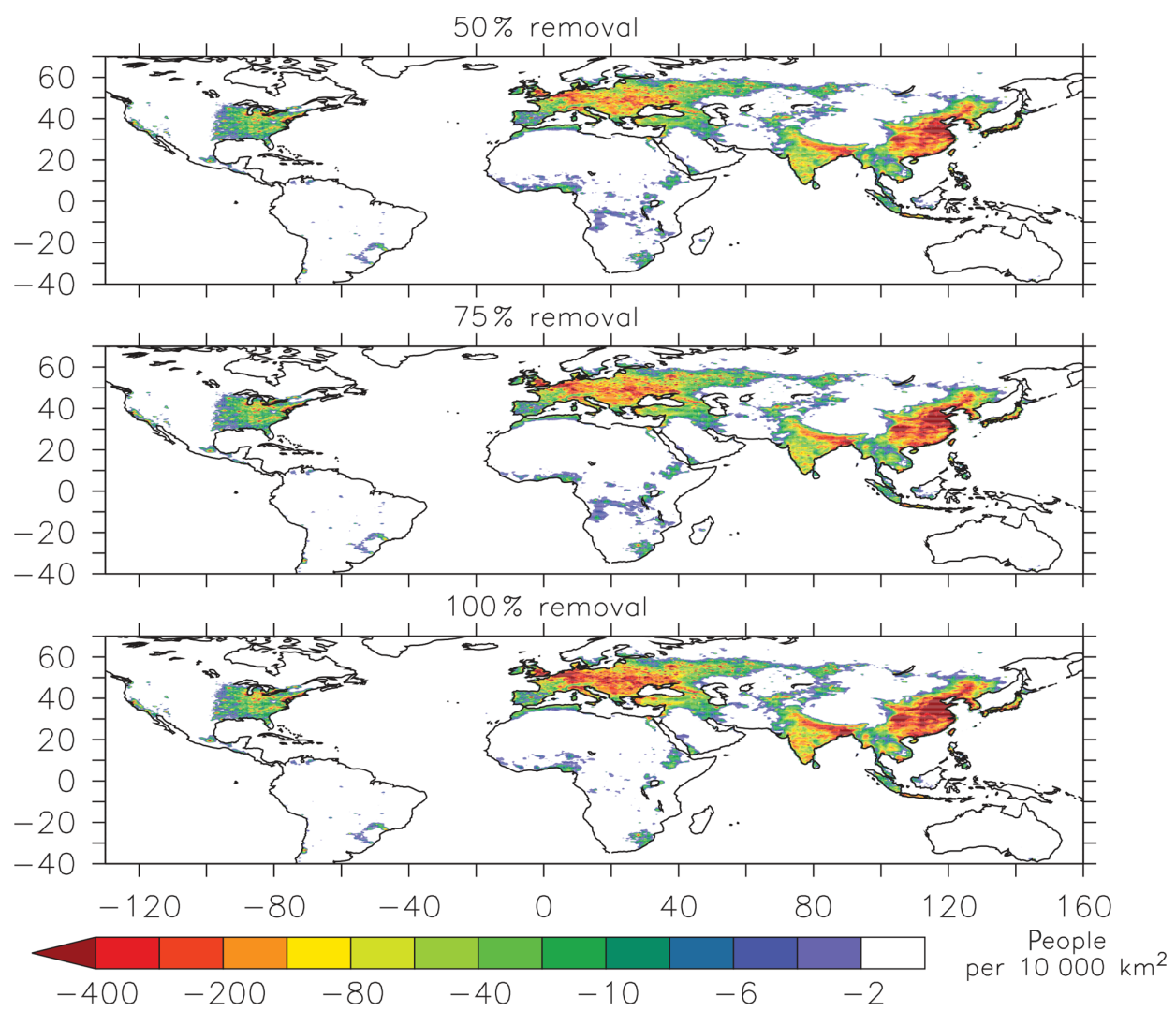

Figure 7. Annual average mortality attributable to $\mathrm{PM}_{2.5}$ concentration changes (in people $/ 10000 \mathrm{~km}^{2}$ ) from the three scenarios with agricultural emissions reductions of 50,75 and $100 \%$ (a, b and $\mathbf{c}$, respectively).

Table 4. Mortality attributable to air pollution in 1000 people $\mathrm{yr}^{-1}$. In parenthesis the minimum-maximum range.

\begin{tabular}{l|rr|rr|rr|rr}
\hline \multirow{2}{*}{ Region } & \multicolumn{2}{|c|}{ REF } & \multicolumn{2}{|c|}{ REF_50 } & \multicolumn{2}{|c}{ REF_75 } & \multicolumn{2}{c}{ REF_100 } \\
& average & range & average & range & average & range & average & range \\
\hline Europe & 277 & $(148-414)$ & 225 & $(107-361)$ & 176 & $(66-313)$ & 55 & $(9-165)$ \\
North America & 54 & $(21-100)$ & 38 & $(11-81)$ & 26 & $(6-65)$ & 14 & $(4-39)$ \\
South Asia & 778 & $(410-1140)$ & 753 & $(396-1107)$ & 750 & $(395-1102)$ & 696 & $(365-1030)$ \\
East Asia & 1381 & $(607-1929)$ & 1275 & $(553-1812)$ & 1195 & $(514-1719)$ & 1037 & $(447-1527)$ \\
World & 3155 & $(1523-4603)$ & 2905 & $(1375-4313)$ & 2739 & $(1280-4123)$ & 2353 & $(1106-3619)$ \\
\hline
\end{tabular}

tions of Burnett et al. (2014) are used, which shows how fine-particulate matter is associated with health impacts, through chronic obstructive pulmonary disease (COPD), acute lower respiratory infections (ALRI), cerebrovascular disease (CEV), ischaemic heart disease (IHD) and lung cancer (LC). Here mortality attributable to $\mathrm{PM}_{2.5}$ at $50 \%$ relative humidity has been estimated; thus it does not account for ozone-related mortality through COPD, which is $\sim 5 \%$ of the total mortality attributable to air pollution (Lelieveld et al., 2015). The model results were interpolated to the finer grid of the population map (Center for International Earth Science Information Network, CIESIN) and, due to the coarse model resolution used in this study, it is expected to have an underestimation of exposure in urban areas. As discussed in the supplement of Lelieveld et al. (2015), an uncertainty range of about $\pm 50 \%$ is estimated for the mortality attributable to air pollution. The results, presented in Table 4 and Fig. 7, show that a reduction of $50 \%$ in agricultural emissions could have a large impact on air-pollutionrelated mortality, reducing it worldwide by $\sim 8 \%$, i.e., af-

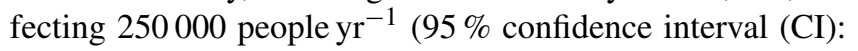
148-290). North America would benefit from a large relative change, reducing the number of deaths by $\sim 30 \%(16000$ people $\mathrm{yr}^{-1}$; $95 \%$ CI: $\left.10-19\right)$, followed by Europe ( $\sim 19 \%$, 52000 people $\mathrm{yr}^{-1}$; $95 \%$ CI: 41-53) and East Asia ( 8\%, 105000 people $\mathrm{yr}^{-1}$; $95 \%$ CI: 53-116), while almost no effects are found over South Asia $\left(\sim 3 \%, 25000\right.$ people $\mathrm{yr}^{-1}$; $95 \%$ CI: 14-33). The relatively large effect in North America 
is explained by the shape of the integrated response function (Burnett et al., 2014), which predicts a steep change in the attributable fraction at relatively low $\mathrm{PM}_{2.5}$ concentrations. If it were possible to fully phase out agricultural emissions, the global reduction of $\mathrm{PM}_{2.5}$-related mortality would reduce by about 801000 people $\mathrm{yr}^{-1}$ (95\% CI: 417-984). In Europe the number would be reduced by about 222000 (95\% CI: 139-249), in North America by 40000 (95\% CI: 17-61), in East Asia by about 343000 per year (95\% CI: 159-401) and in South Asia by 82000 per year (95\% CI: 45-110) (Table 4).

Ammonia reduction policies should consider the intricate and nonlinear effects through gas-aerosol partitioning and multiphase chemistry (including aerosol $\mathrm{pH}$ changes), and therefore a coherent decrease of ammonia, nitrogen and sulfur emissions is recommended. A coupled reduction of $\mathrm{NH}_{3}$ and acid precursor emissions (e.g., $\mathrm{SO}_{2}$ ) cannot only limit the decrease in aerosol $\mathrm{pH}$ but can also lead to a more efficient reduction of $\mathrm{PM}_{2.5}$ concentrations than an $\mathrm{NH}_{3}$ emission control alone, as shown by (Tsimpidi et al., 2007). In the electronic supplement, a table showing the changes in mortality for the top 100 most populated countries is presented. Consistently with the results of Lee et al. (2015), central and eastern European countries would benefit strongly from agricultural emission reductions, drastically decreasing the per capita air-pollution-related mortality. This can be seen also in Fig. 5, as the strongest relative changes in $\mathrm{PM}_{2.5}$ due to agricultural emissions reduction are found in central and eastern Europe, where a $50 \%$ emission reduction would decrease mortality attributable to air pollution by $\sim 15-20 \%$.

It must be emphasized that, although many epidemiological studies have linked long-term $\mathrm{PM}_{2.5}$ exposure to public health outcome, it is yet unclear whether any particular aerosol components and/or source categories are predominantly responsible for air-pollution-related mortality. The debate is open and firm conclusions of a specific relationship have not been reached (Harrison and Yin, 2000; Reiss et al., 2007), although it is expected that some aerosol components may be more toxic than others (Shiraiwa et al., 2012; Mar et al., 2006; Ito et al., 2006).

\section{Conclusions}

Pinder et al. (2007) showed that in North America emission controls of $\mathrm{SO}_{2}$ and $\mathrm{NO}_{x}$ are likely to be very costly and probably less efficient than decreasing agricultural emissions. Therefore, the regulation of ammonia emissions from agricultural activities offers the possibility of relatively costeffective control policies for $\mathrm{PM}_{2.5}$. Our model simulations indicate that a $50 \%$ decrease of ammonia emissions could reduce the annual, geographical average near-surface $\mathrm{PM}_{2.5}$ concentrations up to $\sim 1.0(11 \%), 0.3(8 \%), 1.6(5 \%)$ and $0.6(2 \%) \mu \mathrm{g} \mathrm{m}^{-3}$ in Europe, North America, East Asia and South Asia, respectively. The reduction can even be larger in winter (up to $\sim 1.3(11 \%), 0.6(15 \%), 2.2(5 \%)$ and 1.0
(3\%) $\mu \mathrm{g} \mathrm{m}^{-3}$, respectively) when particulate ammonium nitrate concentrations are typically higher than in summer.

Our model simulations underscore the strong nonlinearity that plays a role in the sulfate-nitrate-ammonia system, which affects the efficiency of $\mathrm{PM}_{2.5}$ controls, especially in summer when the sulfate / nitrate ratio is high. A strong reduction of $\mathrm{PM}_{2.5}$ in response to $\mathrm{NH}_{3}$ emission regulation is expected once the ammonia-limited regime is reached. As a result, the possible $\mathrm{PM}_{2.5}$ reduction could be as large as $\sim 34$ and $\sim 17 \%$ in Europe and North America, respectively. Our results also suggest that ammonia emission controls could reduce the particle $\mathrm{pH}$ up to $1.5 \mathrm{pH}$ units in East Asia in winter and more than $1.7 \mathrm{pH}$ units in South Asia, theoretically assuming complete agricultural emission removal, which could have repercussions for the reactive uptake of gases from the gas phase and the outgassing of relative weak acids.

Furthermore, the global mortality attributable to $\mathrm{PM}_{2.5}$ could be reduced by $\sim 250000$ (95\% CI: 148-290) people $\mathrm{yr}^{-1}$ worldwide worldwide by decreasing agricultural emissions by $50 \%$, with a gain of $16000(30 \%), 52000$ (19\%), $25000(3 \%)$ and $105000(8 \%)$ people $\mathrm{yr}^{-1}$ in North America, Europe, South and East Asia, respectively. A total phase-out of agricultural emissions would even reduce the mortality attributable to air pollution worldwide by about 801000 people $\mathrm{yr}^{-1}(25 \%)$, in Europe by about 222000 people $\mathrm{yr}^{-1}(80 \%)$, in North America by about 40000 people $\mathrm{yr}^{-1}(74 \%)$, in South Asia by about 82000 people $\mathrm{yr}^{-1}$ $(10 \%)$ and in East Asia by about 343000 people $\mathrm{yr}^{-1}(25 \%)$. These strong impacts are related to the nonlinear responses in both the sulfate-nitrate-ammonia system and the exposureresponse functions at relatively low $\mathrm{PM}_{2.5}$ concentrations.

Therefore, emission control policies, especially in North America and Europe, should involve strong ammonia emission decreases to optimally reduce $\mathrm{PM}_{2.5}$ concentrations as well as further reductions in sulfur and nitrogen oxides emissions to avoid strong acidification of particles.

Data availability. The data from all model integrations are available from the authors upon request.

\section{The Supplement related to this article is available online at https://doi.org/10.5194/acp-17-12813-2017- supplement.}

Competing interests. The authors declare that they have no conflict of interest.

Special issue statement. This article is part of the special issue "The Modular Earth Submodel System (MESSy) (ACP/GMD interjournal SI)". It is not associated with a conference. 
Acknowledgements. Vlassis A. Karydis acknowledges support from a FP7 Marie Curie Career Integration Grant (project reference 618349). Alexandra P. Tsimpidi acknowledges support from a DFG Individual Grant Programme (project reference TS 335/2-1).

The article processing charges for this open-access publication were covered by the Max Planck Society.

Edited by: Qiang Zhang

Reviewed by: two anonymous referees

\section{References}

Aneja, V. P., Blunden, J., Roelle, P. A., Schlesinger, W. H., Knighton, R., Niyogi, D., Gilliam, W., Jennings, G., and Duke, C. S.: Workshop on agricultural air quality: state of the science, Atmos. Environ., 42, 3195-3208, 2008.

Battye, W., Aneja, V. P., and Roelle, P. A.: Evaluation and improvement of ammonia emissions inventories, Atmos. Environ., 37, 3873-3883, https://doi.org/10.1016/S1352-2310(03)00343$1,2003$.

Bauer, S. E., Tsigaridis, K., and Miller, R.: Significant atmospheric aerosol pollution caused by world food cultivation, Geophys. Res. Lett., 43, 5394-5400, 2016.

Behera, S. N., Sharma, M., Aneja, V. P., and Balasubramanian, R.: Ammonia in the atmosphere: a review on emission sources, atmospheric chemistry and deposition on terrestrial bodies, Environ. Sci. Pollut. R., 20, 8092-8131, 2013.

Bessagnet, B., Beauchamp, M., Guerreiro, C., de Leeuw, F., Tsyro, S., Colette, A., Meleux, F., Rouïl, L., Ruyssenaars, P., Sauter, F., Velders, G. J. M., Foltescu, V. L., and van Aardenne, J.: Can further mitigation of ammonia emissions reduce exceedances of particulate matter air quality standards?, Environ. Sci. Policy, 44, 149-163, 2014.

Beusen, A., Bouwman, A., Heuberger, P., Van Drecht, G., and Van Der Hoek, K.: Bottom-up uncertainty estimates of global ammonia emissions from global agricultural production systems, Atmos. Environ., 42, 6067-6077, 2008.

Brandt, J., Silver, J. D., Christensen, J. H., Andersen, M. S., Bønløkke, J. H., Sigsgaard, T., Geels, C., Gross, A., Hansen, A. B., Hansen, K. M., Hedegaard, G. B., Kaas, E., and Frohn, L. M.: Contribution from the ten major emission sectors in Europe and Denmark to the health-cost externalities of air pollution using the EVA model system - an integrated modelling approach, Atmos. Chem. Phys., 13, 7725-7746, https://doi.org/10.5194/acp13-7725-2013, 2013.

Burnett, R. T., Pope III, C. A., Ezzati, M., Olives, C., Lim, S. S., Mehta, S., Shin, H. H., Singh, G., Hubbell, B., Brauer, M., Ross, A. H., Smith, K. R., Balmes, J. R., Bruce, N. G., Kan, H., Laden, F., Prüss-Ustün, A., Turner, M. C., Gapstur, S. M., Diver, W. R., and Cohen, A.: An integrated risk function for estimating the global burden of disease attributable to ambient fine particulate matter exposure, Environ. Health Perspect., 122, 397-403, 2014.

Center for International Earth Science Information Network (CIESIN), (FAO), and de Agricultura Tropical (CIAT): Gridded Population of the World, Version 3 (GPWv3): Population Count Grid, Future Estimates., 2005.
Crippa, M., Janssens-Maenhout, G., Dentener, F., Guizzardi, D., Sindelarova, K., Muntean, M., Van Dingenen, R., and Granier, C.: Forty years of improvements in European air quality: regional policy-industry interactions with global impacts, Atmos. Chem. Phys., 16, 3825-3841, https://doi.org/10.5194/acp-163825-2016, 2016.

Delgado, C., Rosegrant, M., Steinfeld, H., Ehui, S., and Courbois, C.: Livestock to 2020: the next food revolution, Outlook Agr., 30, 27-29, 2001.

de Meij, A., Krol, M., Dentener, F., Vignati, E., Cuvelier, C., and Thunis, P.: The sensitivity of aerosol in Europe to two different emission inventories and temporal distribution of emissions, Atmos. Chem. Phys., 6, 4287-4309, https://doi.org/10.5194/acp-64287-2006, 2006.

De Meij, A., Thunis, P., Bessagnet, B., and Cuvelier, C.: The sensitivity of the CHIMERE model to emissions reduction scenarios on air quality in Northern Italy, Atmos. Environ., 43, 1897-1907, 2009.

de Meij, A., Pozzer, A., and Lelieveld, J.: Trend analysis in aerosol optical depths and pollutant emission estimates between 2000 and 2009, Atmos. Environ., 51, 75-85, https://doi.org/10.1016/j.atmosenv.2012.01.059, 2012a.

de Meij, A., Pozzer, A., Pringle, K., Tost, H., and Lelieveld, J.: EMAC model evaluation and analysis of atmospheric aerosol properties and distribution with a focus on the Mediterranean region, Atmos. Res., 114-115, 38-69, https://doi.org/10.1016/j.atmosres.2012.05.014, 2012b.

Dentener, F., Kinne, S., Bond, T., Boucher, O., Cofala, J., Generoso, S., Ginoux, P., Gong, S., Hoelzemann, J. J., Ito, A., Marelli, L., Penner, J. E., Putaud, J.-P., Textor, C., Schulz, M., van der Werf, G. R., and Wilson, J.: Emissions of primary aerosol and precursor gases in the years 2000 and 1750 prescribed data-sets for AeroCom, Atmos. Chem. Phys., 6, 43214344, https://doi.org/10.5194/acp-6-4321-2006, 2006.

Doering, U., Monni, S., Pagliari, V., Orlandini, L., van Aardenne, J., and SanMartin, F.: CIRCE report D8.1.1 : Emission inventory for the past period 1990-2005 on 0.1x0.1 grid, Tech. rep., Project FP6: 6.3, No. 036961, 2009a.

Doering, U., van Aardenne, J., Monni, S., Pagliari, V., Orlandini, L., and SanMartin, F.: CIRCE report D8.1.2 - Evaluation emission database 1990-2005, Tech. rep., Project FP6: 6.3, No. 036961, 2009b.

Doering, U., van Aardenne, J., Monni, S., Pagliari, V., Orlandini, L., and SanMartin, F.: CIRCE report D8.1.3 - Update of gridded emission inventories, addition of period 1990-1999 to 20002005 dataset, Tech. rep., Project FP6: 6.3, No. 036961, 2009c.

Emmons, L. K., Hauglustaine, D. A., Müller, J.-F., Carroll, M. A., Brasseur, G. P., Brunner, D., Staehelin, J., Thouret, V., and Marenco, A.: Data composites of airborne observations of tropospheric ozone and its precursors, J. Geophys. Res., 105, 20497 20538, 2000.

Fountoukis, C. and Nenes, A.: ISORROPIA II: a computationally efficient thermodynamic equilibrium model for $\mathrm{K}^{+}$ $\mathrm{Ca}^{2+}-\mathrm{Mg}^{2+}-\mathrm{NH}_{4}^{+}-\mathrm{Na}^{+}-\mathrm{SO}_{4}^{2-}-\mathrm{NO}_{3}^{-}-\mathrm{Cl}^{-}-\mathrm{H}_{2} \mathrm{O}$ aerosols, Atmos. Chem. Phys., 7, 4639-4659, https://doi.org/10.5194/acp-74639-2007, 2007.

Goebes, M. D., Strader, R., and Davidson, C.: An ammonia emission inventory for fertilizer application in the United States, At- 
mos. Environ., 37, 2539-2550, https://doi.org/10.1016/S13522310(03)00129-8, 2003.

Harrison, R. M. and Yin, J.: Particulate matter in the atmosphere: which particle properties are important for its effects on health?, Sci. Total Environ., 249, 85-101, 2000.

Heald, C. L., Collett Jr., J. L., Lee, T., Benedict, K. B., Schwandner, F. M., Li, Y., Clarisse, L., Hurtmans, D. R., Van Damme, M., Clerbaux, C., Coheur, P.-F., Philip, S., Martin, R. V., and Pye, H. O. T.: Atmospheric ammonia and particulate inorganic nitrogen over the United States, Atmos. Chem. Phys., 12, 10295-10312, https://doi.org/10.5194/acp-12-10295-2012, 2012.

Holt, J., Selin, N. E., and Solomon, S.: Changes in inorganic fine particulate matter sensitivities to precursors due to large-scale US emissions reductions, Environ. Sci. Technol., 49, 4834-4841, 2015.

IPCC: Climate Change 2013: The Physical Science Basis. Contribution of Working Group I to the Fifth Assessment Report of the Intergovernmental Panel on Climate Change, edited by: Stocker, T., Qin, D., Plattner, G.-K., Tignor, M., Allen, S., Boschung, J., Nauels, A., Xia, Y., Bex, V., and Midgley, P., vol. 2, Cambridge University Press, 2013.

Ito, K., Christensen, W. F., Eatough, D. J., Henry, R. C., Kim, E., Laden, F., Lall, R., Larson, T. V., Neas, L., Hopke, P. K., and Thurston, G. D.: PM source apportionment and health effects: 2. An investigation of intermethod variability in associations between source-apportioned fine particle mass and daily mortality in Washington, DC, J. Expo. Sci. Env. Epid., 16, 300-320, 2006.

Jöckel, P., Sander, R., Kerkweg, A., Tost, H., and Lelieveld, J.: Technical Note: The Modular Earth Submodel System (MESSy) - a new approach towards Earth System Modeling, Atmos. Chem. Phys., 5, 433-444, https://doi.org/10.5194/acp-5-4332005, 2005.

Jöckel, P., Tost, H., Pozzer, A., Brühl, C., Buchholz, J., Ganzeveld, L., Hoor, P., Kerkweg, A., Lawrence, M. G., Sander, R., Steil, B., Stiller, G., Tanarhte, M., Taraborrelli, D., van Aardenne, J., and Lelieveld, J.: The atmospheric chemistry general circulation model ECHAM5/MESSy1: consistent simulation of ozone from the surface to the mesosphere, Atmos. Chem. Phys., 6, 50675104, https://doi.org/10.5194/acp-6-5067-2006, 2006.

Kai, P., Pedersen, P., Jensen, J., Hansen, M. N., and Sommer, S. G.: A whole-farm assessment of the efficacy of slurry acidification in reducing ammonia emissions, Eur. J. Agron., 28, 148-154, 2008.

Karydis, V. A., Tsimpidi, A. P., Lei, W., Molina, L. T., and Pandis, S. N.: Formation of semivolatile inorganic aerosols in the Mexico City Metropolitan Area during the MILAGRO campaign, Atmos. Chem. Phys., 11, 13305-13323, https://doi.org/10.5194/acp-1113305-2011, 2011.

Karydis, V. A., Tsimpidi, A. P., Pozzer, A., Astitha, M., and Lelieveld, J.: Effects of mineral dust on global atmospheric nitrate concentrations, Atmos. Chem. Phys., 16, 1491-1509, https://doi.org/10.5194/acp-16-1491-2016, 2016.

Kuklinska, K., Wolska, L., and Namiesnik, J.: Air quality policy in the US and the EU - a review, Atmospheric Pollution Research, 6, 129-137, 2015.

Lamarque, J., Kyle, G., Meinshausen, M., Riahi, K., Smith, S., van Vuuren, D., Conley, A., and Vitt, F.: Global and regional evolution of short-lived radiatively-active gases and aerosols in the Representative Concentration Pathways, Climatic Change, 109, 191-212, https://doi.org/10.1007/s10584-011-0155-0, 2011.
Lee, C. J., Martin, R. V., Henze, D. K., Brauer, M., Cohen, A., and Donkelaar, A. V.: Response of global particulate-matter-related mortality to changes in local precursor emissions, Environ. Sci. Technol., 49, 4335-4344, 2015.

Lelieveld, J., Evans, J., Fnais, M., Giannadaki, D., and Pozzer, A.: The contribution of outdoor air pollution sources to premature mortality on a global scale, Nature, 525, 367-371, 2015.

Lim, S. S., Vos, T., Flaxman, A. D., Danaei, G., Shibuya, K., AdairRohani, H., AlMazroa, M. A., Amann, M., Anderson, H. R., Andrews, K. G., et al.: A comparative risk assessment of burden of disease and injury attributable to 67 risk factors and risk factor clusters in 21 regions, 1990-2010: a systematic analysis for the Global Burden of Disease Study 2010, Lancet, 380, 2224-2260, 2013.

Lorenz, F. and Steffens, G.: Effect of application techniques on ammonia losses and herbage yield following slurry application to grassland, edited by: Jarvis, S. C. and Pain, B. F., Gaseous Nitrogen Emissions from Grasslands, CAB International, Wallingford 287-292, 1997.

Makar, P. A., Moran, M. D., Zheng, Q., Cousineau, S., Sassi, M., Duhamel, A., Besner, M., Davignon, D., Crevier, L.-P., and Bouchet, V. S.: Modelling the impacts of ammonia emissions reductions on North American air quality, Atmos. Chem. Phys., 9, 7183-7212, https://doi.org/10.5194/acp-9-7183-2009, 2009.

Mar, T. F., Ito, K., Koenig, J. Q., Larson, T. V., Eatough, D. J., Henry, R. C., Kim, E., Laden, F., Lall, R., Neas, L., Stälzel, M., Paatero, P., and Hopke, P. K., and Thurston, G. D.: PM source apportionment and health effects. 3. Investigation of inter-method variations in associations between estimated source contributions of PM2.5 and daily mortality in Phoenix, AZ, J. Expo. Sci. Env. Epid., 16, 311, 2006.

Megaritis, A. G., Fountoukis, C., Charalampidis, P. E., Pilinis, C., and Pandis, S. N.: Response of fine particulate matter concentrations to changes of emissions and temperature in Europe, Atmos. Chem. Phys., 13, 3423-3443, https://doi.org/10.5194/acp13-3423-2013, 2013.

Misselbrook, T. H., Smith, K. A., Johnson, R. A., and Pain, B. F.: Slurry Application Techniques to reduce Ammonia Emissions: Results of some UK Field-scale Experiments, Biosyst. Eng., 81, 313-321, 2002.

Muller, N. Z. and Mendelsohn, R.: Measuring the damages of air pollution in the United States, J. Environ. Econ. Manag., 54, 114, 2007.

Nenes, A., Pandis, S. N., and Pilinis, C.: ISORROPIA: A new thermodynamic equilibrium model for multiphase multicomponent inorganic aerosols, Aquat. Geochem., 4, 123-152, https://doi.org/10.1023/A:1009604003981, 1998a.

Nenes, A., Pandis, S. N., and Pilinis, C.: Continued Development and Testing of a New Thermodynamic Aerosol Module for Urban and Regional Air Quality Models, Atmos. Environ., 33, 1553-1560, 1998b.

Pathak, R. K., Wang, T., Ho, K., and Lee, S.: Characteristics of summertime PM 2.5 organic and elemental carbon in four major Chinese cities: implications of high acidity for water-soluble organic carbon (WSOC), Atmos. Environ., 45, 318-325, 2011.

Paulot, F. and Jacob, D. J.: Hidden cost of US agricultural exports: particulate matter from ammonia emissions, Environ. Sci. Technol., 48, 903-908, 2014. 
Paulot, F., Jacob, D. J., Pinder, R., Bash, J., Travis, K., and Henze, D.: Ammonia emissions in the United States, European Union, and China derived by high-resolution inversion of ammonium wet deposition data: Interpretation with a new agricultural emissions inventory (MASAGE_NH3), J. Geophys. Res., 119, 43434364, 2014.

Paulot, F., Fan, S., and Horowitz, L.: Contrasting seasonal responses of sulfate aerosols to declining $\mathrm{SO}_{2}$ emissions in the Eastern US: implications for the efficacy of $\mathrm{SO}_{2}$ emission controls, Geophys. Res. Lett., 44, https://doi.org/10.1002/2016GL070695, 2016.

Pinder, R., Gilliland, A., and Dennis, R.: Environmental impact of atmospheric $\mathrm{NH}_{3}$ emissions under present and future conditions in the eastern United States, Geophys. Res. Lett., 35, https://doi.org/10.1002/2016GL070695, 2008.

Pinder, R. W., Adams, P. J., and Pandis, S. N.: Ammonia emission controls as a cost-effective strategy for reducing atmospheric particulate matter in the eastern United States, Environ. Sci. Technol., 41, 380-386, 2007.

Pozzer, A., Jöckel, P., Tost, H., Sander, R., Ganzeveld, L., Kerkweg, A., and Lelieveld, J.: Simulating organic species with the global atmospheric chemistry general circulation model ECHAM5/MESSy1: a comparison of model results with observations, Atmos. Chem. Phys., 7, 2527-2550, https://doi.org/10.5194/acp-7-2527-2007, 2007.

Pozzer, A., Jöckel, P., and Van Aardenne, J.: The influence of the vertical distribution of emissions on tropospheric chemistry, Atmos. Chem. Phys., 9, 9417-9432, https://doi.org/10.5194/acp-99417-2009, 2009.

Pozzer, A., de Meij, A., Pringle, K. J., Tost, H., Doering, U. M., van Aardenne, J., and Lelieveld, J.: Distributions and regional budgets of aerosols and their precursors simulated with the EMAC chemistry-climate model, Atmos. Chem. Phys., 12, 961-987, https://doi.org/10.5194/acp-12-961-2012, 2012a.

Pozzer, A., Zimmermann, P., Doering, U. M., van Aardenne, J., Tost, H., Dentener, F., Janssens-Maenhout, G., and Lelieveld, J.: Effects of business-as-usual anthropogenic emissions on air quality, Atmos. Chem. Phys., 12, 6915-6937, https://doi.org/10.5194/acp-12-6915-2012, 2012b.

Pringle, K. J., Tost, H., Message, S., Steil, B., Giannadaki, D., Nenes, A., Fountoukis, C., Stier, P., Vignati, E., and Lelieveld, J.: Description and evaluation of GMXe: a new aerosol submodel for global simulations (v1), Geosci. Model Dev., 3, 391-412, https://doi.org/10.5194/gmd-3-391-2010, 2010a.

Pringle, K. J., Tost, H., Pozzer, A., Pöschl, U., and Lelieveld, J.: Global distribution of the effective aerosol hygroscopicity parameter for $\mathrm{CCN}$ activation, Atmos. Chem. Phys., 10, 52415255, https://doi.org/10.5194/acp-10-5241-2010, 2010 b.

Pye, H., Liao, H., Wu, S., Mickley, L., Jacob, D., Henze, D., and Seinfeld, J.: Effect of changes in climate and emissions on future sulfate-nitrate-ammonium aerosol levels in the United States, J. Geophys. Res., 114, 1-18, 2009.

Redington, A., Derwent, R., Witham, C., and Manning, A.: Sensitivity of modelled sulphate and nitrate aerosol to cloud, $\mathrm{pH}$ and ammonia emissions, Atmos. Environ., 43, 3227-3234, 2009.

Reiss, R., Anderson, E. L., Cross, C. E., Hidy, G., Hoel, D., McClellan, R., and Moolgavkar, S.: Evidence of health impacts of sulfate-and nitrate-containing particles in ambient air, Inhal. Toxicol., 19, 419-449, 2007.
Roeckner, E., Brokopf, R., Esch, M., Giorgetta, M., Hagemann, S., Kornblueh, L., Manzini, E., Schlese, U., and Schulzweida, U.: Sensitivity of simulated climate to horizontal and vertical resolution in the ECHAM5 atmosphere model, J. Climate, 19, 37713791, 2006.

Sander, R., Kerkweg, A., Jöckel, P., and Lelieveld, J.: Technical note: The new comprehensive atmospheric chemistry module MECCA, Atmos. Chem. Phys., 5, 445-450, https://doi.org/10.5194/acp-5-445-2005, 2005.

Sander, R., Baumgaertner, A., Gromov, S., Harder, H., Jöckel, P., Kerkweg, A., Kubistin, D., Regelin, E., Riede, H., Sandu, A., Taraborrelli, D., Tost, H., and Xie, Z.-Q.: The atmospheric chemistry box model CAABA/MECCA-3.0, Geosci. Model Dev., 4, 373-380, https://doi.org/10.5194/gmd-4-373-2011, 2011.

Schaap, M., van Loon, M., ten Brink, H. M., Dentener, F. J., and Builtjes, P. J. H.: Secondary inorganic aerosol simulations for Europe with special attention to nitrate, Atmos. Chem. Phys., 4, 857-874, https://doi.org/10.5194/acp-4-857-2004, 2004.

Shiraiwa, M., Selzle, K., and Pöschl, U.: Hazardous components and health effects of atmospheric aerosol particles: reactive oxygen species, soot, polycyclic aromatic compounds and allergenic proteins, Free Radical Res., 46, 927-939, 2012.

Sotiropoulou, R., Tagaris, E., and Pilinis, C.: An estimation of the spatial distribution of agricultural ammonia emissions in the Greater Athens Area, Sci. Total Environ., 318, 159-169, 2004.

Sun, K., Tao, L., Miller, D. J., Pan, D., Golston, L. M., Zondlo, M. A., Griffin, R. J., Wallace, H. W., Leong, Y. J., Yang, M. Y. M., Zhang, Y., Mauzerall, D. L., and Zhu, T.: Vehicle Emissions as an Important Urban Ammonia Source in the United States and China, Environ. Sci. Technol., 51, 2472-2481, https://doi.org/10.1021/acs.est.6b02805, 2016.

Thornton, J. A., Kercher, J. P., Riedel, T. P., Wagner, N. L., Cozic, J., Holloway, J. S., Dubé, W. P., Wolfe, G. M., Quinn, P. K., Middlebrook, A. M., Alexander, B., and Brown, S. S.: A large atomic chlorine source inferred from mid-continental reactive nitrogen chemistry, Nature, 464, 271-274, 2010.

Tsimpidi, A. P., Karydis, V. A., and Pandis, S. N.: Response of inorganic fine particulate matter to emission changes of sulfur dioxide and ammonia: The eastern United States as a case study, J. Am. Waste Manage. Assoc., 57, 1489-1498, 2007.

Tsimpidi, A. P., Karydis, V. A., and Pandis, S. N.: Response of fine particulate matter to emission changes of oxides of nitrogen and anthropogenic volatile organic compounds in the Eastern United States, J. Am. Waste Manage. Assoc., 58, 1463-1473, 2008.

van Donkelaar, A., Martin, R. V., Brauer, M., Kahn, R., Levy, R., Verduzco, C., and Villeneuve, P. J.: Global Estimates of Ambient Fine Particulate Matter Concentrations from Satellite-Based Aerosol Optical Depth: Development and Application, Environ. Health Perspect., 118, https://doi.org/10.1289/ehp.0901623, 2010.

van Vuuren, D., Edmonds, J., Kainuma, M., Riahi, K., Thomson, A., Hibbard, K., Hurtt, G., Kram, T., Krey, V., Lamarque, J.-F., Masui, T., Meinshausen, M., Nakicenovic, N., Smith, S., and Rose, S.: The representative concentration pathways: an overview, Climatic Change, 109, 5-31, https://doi.org/10.1007/s10584-0110148-z, 2011a.

van Vuuren, D., Edmonds, J., Kainuma, M., Riahi, K., and Weyant, J.: A special issue on the RCPs, Climatic Change, 109, https://doi.org/10.1007/s10584-011-0157-y, 2011 b. 
Wang, G. H., Zhou, B. H., Cheng, C. L., Cao, J. J., Li, J. J., Meng, J. J., Tao, J., Zhang, R. J., and Fu, P. Q.: Impact of Gobi desert dust on aerosol chemistry of Xi' an, inland China during spring 2009: differences in composition and size distribution between the urban ground surface and the mountain atmosphere, Atmos. Chem. Phys., 13, 819-835, https://doi.org/10.5194/acp-13-8192013, 2013.

Wang, S., Xing, J., Jang, C., Zhu, Y., Fu, J. S., and Hao, J.: Impact assessment of ammonia emissions on inorganic aerosols in East China using response surface modeling technique, Environ. Sci. Technol., 45, 9293-9300, 2011.

Webb, J., Ryan, M., Anthony, S., Brewer, A., Laws, J., Aller, M., and Misselbrook, T.: Cost-effective means of reducing ammonia emissions from UK agriculture using the NARSES model, Atmos. Environ., 40, 7222-7233, 2006.
Weber, R. J., Guo, H., Russell, A. G., and Nenes, A.: High aerosol acidity despite declining atmospheric sulfate concentrations over the past 15 years, Nat. Geosci., 9, 282-285, 2016.

Zhang, Q., Jimenez, J. L., Worsnop, D. R., and Canagaratna, M.: A case study of urban particle acidity and its influence on secondary organic aerosol, Environ. Sci. Technol., 41, 3213-3219, 2007.

Zhang, Y., Wu, S.-Y., Krishnan, S., Wang, K., Queen, A., Aneja, V. P., and Arya, S. P.: Modeling agricultural air quality: Current status, major challenges, and outlook, Atmos. Environ., 42, 3218-3237, 2008.

Zhu, L., Henze, D., Bash, J., Jeong, G.-R., Cady-Pereira, K., Shephard, M., Luo, M., Paulot, F., and Capps, S.: Global evaluation of ammonia bidirectional exchange and livestock diurnal variation schemes, Atmos. Chem. Phys., 15, 12823-12843, https://doi.org/10.5194/acp-15-12823-2015, 2015. 